\title{
The USGS at Embude, New Mexico: 125 Years of Systematic Streamgaging in the United States
}

John Wesley Powell, second Director of the U.S. Geological Survey (USGS), had a vision for the Western United States. In the late 1800s, Powell explored the West as head of the Geographical and Geological Survey of the Rocky Mountain Region. He devoted a large part of "Report on the Lands of the Arid Region of the United States with a more detailed account of the land of Utah with maps," his 1878 report to the General Land Office on the lands west of the 100th meridian, to the feasibility of "reclaiming" large portions of this arid land (Powell, 1879).

Powell recognized that the availability of water was key to the wise settlement of the region. He proposed to inventory all streams in the West to evaluate the potential for irrigation. The essential first step was to gage the flows of the rivers and streams.

A few cities in the Eastern United States had established primitive streamgages as early as the 1870s to acquire data needed for the design of their water supply systems. Their methods generally used constructed channels and dams to enable accurate gaging. These methods were not feasible in the West, and certainly not on the vast scale and extreme range of flows common to western streams. New, more flexible techniques were needed. A site was chosen where these methods could be worked out and developed in a practical setting.

\section{amp Embudo and the First}

\section{USGS Streamgage}

A site on the Rio Grande near the town of Embudo, New Mexico, was established as the first USGS training camp for hydrographers. Frederick H. Newell, first appointed by Powell as assistant hydraulic engineer and later serving as first director of the Bureau of Reclamation, was in charge of the camp. The camp was established in December of 1888 with a class of 14 student hydrographers. Staff included 3 instructors, 2 laborers, a packer, and a cook.

Because equipment was initially lacking, the students used float measurements and crosssectional surveys to compute discharge. Later, an oceanographic current meter borrowed from the U.S. Coast and Geodetic Survey and the Navy Department was modified to fit the unique challenges of the Rio Grande: shallow, fastmoving water and soft, mobile channel beds. Ultimately, the students fabricated improved velocity meters and suspension systems to measure the essential elements of streamflow: cross-sectional area and velocity.

The Rio Grande at Embudo streamgage was established adjacent to the railroad station in January 1889 , becoming the first USGS streamgage. Official training at Camp Embudo ended in April 1889, with 10 students completing the training to be classified as "hydrographers" or "assistant hydrographers." The newly trained hydrographers dispersed to locations throughout the West.

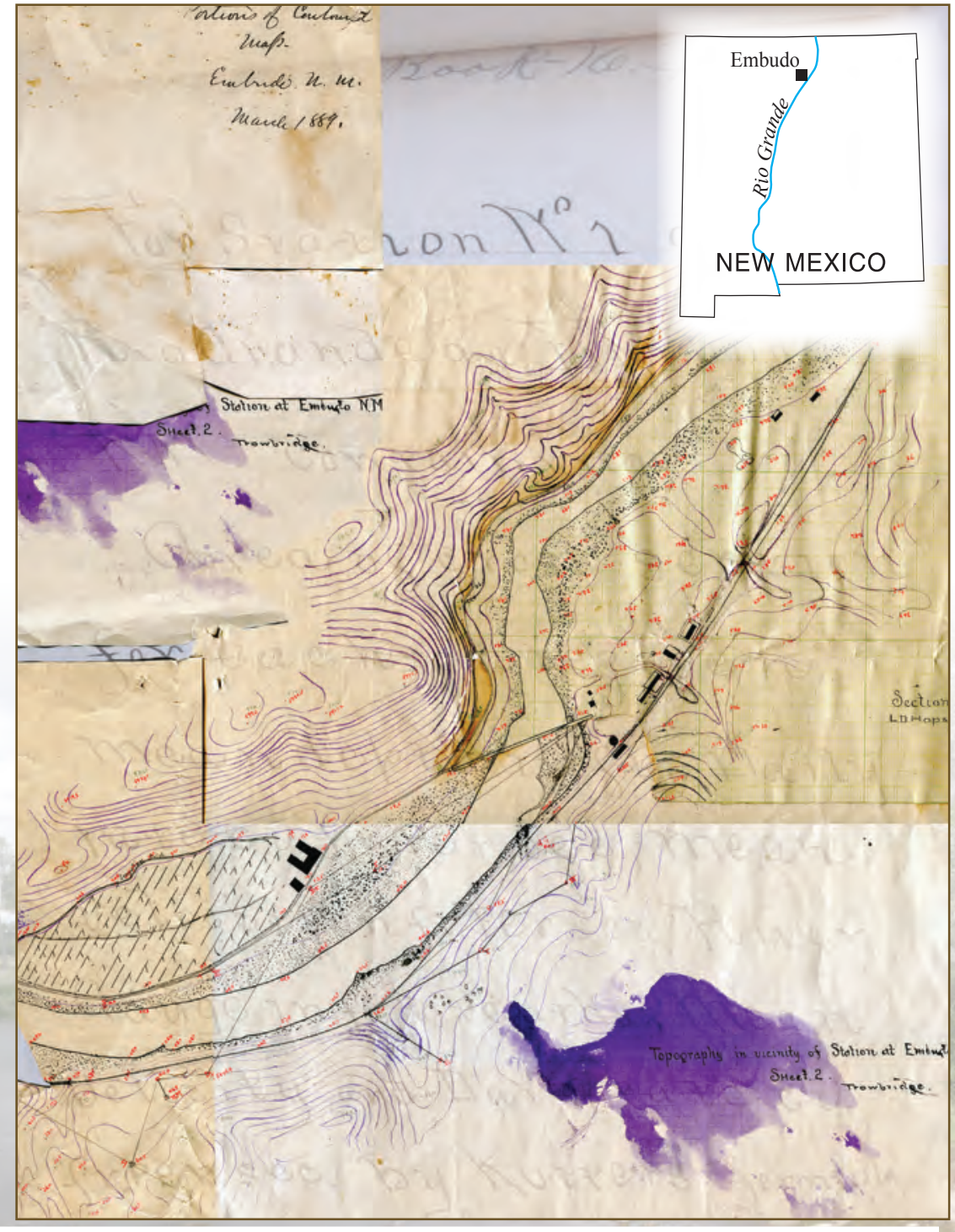


Why a Remote Outpost Like Embudo?

Congressional funding for the Irrigation Survey (an early branch of the USGS) was intended for the arid West, meaning all land west of the 100th meridian. A component of the planned irrigation survey was an inventory of all streamflow in order to evaluate the irrigation potential to nearby land areas. The first step in this inventory was to train hydrographers and develop equipment and techniques for measuring streamflow in an arid environment. Getting the program underway as soon as possible after Congressional funding in October 1888 meant that weather was a consideration. Most northern streams would soon be frozen, leaving the southwest as the only practical alternative. Embudo was located far enough south for the Rio Grande to have flowing water throughout the winter. In addition, railroad transportation connected directly with the Embudo site, expediting transport of personnel and equipment and providing access to outside resources. This access would become important in the development and adaptation of equipment and techniques that would become the foundation of USGS streamgaging methods.

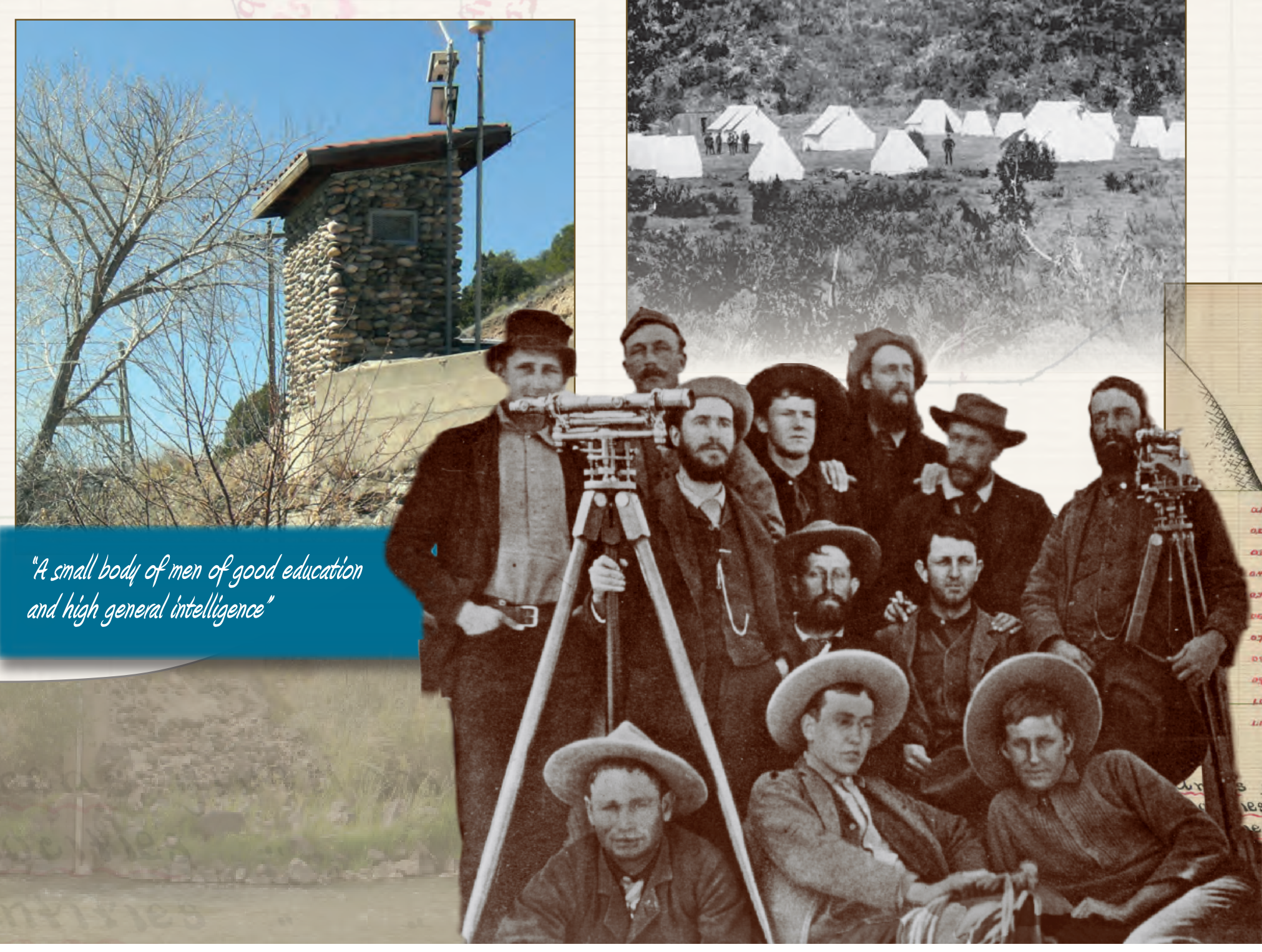




\section{he Evolution of Streamflow Measurement Techniques}

Equipment was refined over the years, but the basic design of mechanical velocity meters and streamflow measurement techniques remained essentially the same throughout the 1900s. Mechanical velocity meters in the form of rod- or cable-suspended meters with rotating cups were the norm and continue in use today. In recent years, velocity meters have been largely replaced by hydroacoustic equipment such as the acoustic Doppler current profilers (ADCPs). An ADCP measures the Doppler shift in the frequency of acoustic signals that are reflected from materials suspended in and moving with the water to estimate flow velocity and that are reflected from the river bed to compute boat location and channel width. It uses the time of travel of signals reflected from the riverbed to estimate channel depth.

Use of hydroacoustic technology has improved efficiency and increased the quality of discharge measurements, and has made it possible to determine discharge in some flood or low-flow conditions where measurement was not previously possible. The use of hydroacoustic instruments has developed rapidly since 2000 , and at present (2014), 80 percent of USGS discharge measurements use hydroacoustic instruments. For more information, visit http://hydroacoustics.usgs.gov/.



Interest in USGS methods of streamgaging quickly spread east. Streamflow information was needed there to manage water supplies and to design hydroelectric powerplants. For 125 years, USGS streamflow information has provided the scientific basis for protecting, managing, and sustaining freshwater that is safe and available for drinking and other competing water demands, including irrigation, energy, industry, recreation, and ecosystem health. With the ability to transmit collected data from field sites to USGS offices by satellite, phone, or radio, much of the information is available in near-real time (http://waterdata.usgs. gov/nwis), which is critical to protect and minimize loss of life and property from water hazards, including floods, droughts, and debris flows.

The USGS streamgage network, like many USGS Water Resources programs, depends on partner funding. More than 70 percent of about 8,000 streamgages across the Nation are supported through joint contributions by more than 850 local, State, and tribal partners and the USGS to address specific partner priorities through the Cooperative Water Program (https://water.usgs.gov/coop/). Federal partners support streamgages providing data critical to the operation of other Federal programs. In addition, about 3,100 streamgages meet the targeted, long-term priorities established by the National Streamflow Information Program (http://water.usgs.gov/nsip/). This program is designed to meet Federal responsibilities associated with flood forecasting; monitoring flows across international, interstate, and tribal borders; tracking flow in major river basins; and assessing long-term climatic, land-use, and human impacts on streamflow and water quality in different vironmental settings across the Nation.

Most USGS streamgages provide information for more than one use. Uses of the streamflow information collected at Embudo are a case in point: The National Weather Service uses the information for river forecasts, but local, State, and Federal agencies also use the data (1) to account for inflow from the Rio Grande above the Rio Chama as part of the Rio Grande Compact, (2) to help time releases and account for waters from the San Juan-Chama transbasin diversion, and (3) to help establish and protect water rights. Survey Professional Paper 778, 23 p., http://pubs.usgs.gov/ Series Monograph, 193 p., 3 pls., http://pubs.usgs.gov/ egner, W.E., 1954, Beyond the hundredth meridian-John Wesley Powell and the second opening of the West: Lincoln, a Press, 438 p.

- By Mark A. Gunn, Anne Marie Matherne, and

Publishing support provided by 